\title{
ANALISIS FITOKIMIA DAN PENENTUAN NILAI LC50 EKSTRAK METANOL DAUN LIWAS
}

\author{
Gerry Sumihe $^{1)}$ Max R. J.Runtuwene ${ }^{1)}$ dan Johnly A. Rorong ${ }^{1)}$ \\ 1)Jurusan Kimia FMIPA UNSRAT, Manado \\ e-mail: 004Gerry@gmail.com; max_runtuwene@yahoo.com; rorongjohnly@yahoo.co.id
}

\begin{abstract}
ABSTRAK
Penentuan nilai $\mathrm{LC}_{50}$ dari ekstrak metanol daun liwas menggunakan metode Brine Shrimp Lethality Test (BSLT) terhadap hewan indikator udang Artemia salina menunjukkan nilai $\mathrm{LC}_{50}$ dari A. salina bersifat sangat toksik.Nilai $\mathrm{LC}_{50}$ yang didapatkan sebesar 15,696 mg/L. Nilai $\mathrm{LC}_{50}$ ditentukan dengan menggunakan metode SPSS 20.0.Ekstrak metanol daun liwas mengandung kandungan senyawa metabolit sekunder seperti flavonoid, tanin dan saponin sebagai hasil uji fitokimia.
\end{abstract}

Kata kunci: BSLT, Daun Liwas, Metabolit Sekunder,LC 50.

\section{PHYTOCHEMICAL ANALYSIS AND DETERMINING LC50 VALUE OF LIWAS LEAVE METHANOL EXTRACT}

\begin{abstract}
Determination of $\mathrm{LC}_{50}$ of methanol extract of leaves liwas using Brine Shrimp Lethality Test (BSLT) against animal indicator shrimp Artemia salina showed $\mathrm{LC}_{50}$ values of A. salina is highly toxic. $\mathrm{LC}_{50}$ values were obtained at $15.696 \mathrm{mg} / \mathrm{L}$. $\mathrm{LC}_{50}$ values determined using SPSS 20.0. Liwas leaf methanol extract contains compounds secondary metabolites such as flavonoids, tannins and saponins as phytochemical test results.
\end{abstract}

Keywords: BSLT, Leaves Liwas, Secondary Metabolites, $\mathrm{LC}_{50}$.

\section{PENDAHULUAN}

Daun liwas merupakan salah satu tanaman obat yang sering digunakan sebagai salah satu obat tradisional yang digunakan sebagaianti rabies dan infeksi oleh masyarakat desa Liwutung, Minahasa Tenggara, Sulawesi Utara.

Flavonoid, saponin, dan tanin merupakansenyawa metabolit sekunder yang berkhasiat sebagai anti histamin, antioksidan, anti virus, anti bakteri, anti inflamasi sampai anti kanker (Harmanto, 2002). Beberapa senyawa metabolit sekunder merupakan senyawa polar dengan gugus $\mathrm{OH}^{-}$dan dapat larut dalam pelarut polar seperti etanol, metanol, butanol dan air (Markham, 1988).

Metanol digunakan sebagai pelarut dalam ekstraksi maserasi karena metanol bersifat sebagai pelarut polar mampu melarutkan unsur-unsur bioaktif yang bersifat polar pada tanaman herba medisinalis (Santosa, 1995).

Khasiat dari daun liwas perlu dikaji secara ilmiah tentang kandungan senyawa yang terkandung dalam daun liwas tersebut. Berdasarkan hal terseebut perlu dilakukan penelitian uji toksisitas ekstrak metanol daun liwas terhadap udang A. salina Leach dengan menggunakan metode Brine Shrimp Lethality Test (BSLT).

\section{METODOLOGI PENELITIAN}

\section{Waktu dan Tempat}

Penelitian dilakukan pada bulan JuliSeptember 2013 di Laboratorium Kimia Advance dan Laboratorium Kimia Organik Jurusan Kimia Fakultas Matematika dan Ilmu Pengetahuan Alam Universitas Sam Ratulangi. 


\section{Bahan}

Bahan yang digunakan adalah: sampel daun liwas, $\mathrm{HCl}$, telur udang Artemia salina, aquades, garam tak beryodium, serbuk magnesium, metanol, $\mathrm{FeCl}_{3}$, vaselin dan aluminium foil.

\section{Alat}

Alat yang digunakan antara lain tabung reaksi, neraca analitik, rotary evaporator, waterbath, beker gelas, spatula, kertas saring, lampu pijar 40 watt, wadah bening, blender, thermometer, labu takar 100 $\mathrm{mL}$, Erlenmeyer, desikator, pipet $10 \mathrm{~mL}$, pipet tetes, lemari asam, kac pembesar dan gelas arloji.

\section{Prosedur Penelitian \\ Preparasi Sampel}

Sebelum dikeringkan daun liwas dicuci dan dipetik kemudian dikeringkan dalam oven pada $40^{\circ} \mathrm{C}$.daun dihaluskan menggunakan blender sampai menjadi serbuk dan diayak dengan ayakan 65 mesh (Silaban, 2009).

\section{Kadar Air}

Serbuk sampel yang sudah diayak ditimbang untuk ditentukan kada air. Sampel serbuk daun liwas sebanyak 170,61 g sebagai berat awal. Sampel yang sudah diimbang dimasukkan ke dalam oven dengan suhu $105^{\circ} \mathrm{C}$ selama 3 jam.Didinginkan selama 30 menit dalam desikator dan kemudian ditimbang sebagai berat akhir. Perlakuan yang sama dilakukan sebanyak tiga kali (Sudarmadji, 1989).

\section{Ekstraksi Maserasi}

Sampel sebanyak $50 \mathrm{~g}$ diekstraksi dengan pelarut metanol menggunakan metode ekstraksi maserasi. Sampel didiamkan dalam $250 \mathrm{~mL}$ metanol selama 24 jam dan diaduk.Filtrat disaring dan ampas dipisahkan dari filtrat menggunakan kertas saring. Sebanyak $250 \mathrm{~mL}$ metanol ditambahkan lagi ke dalam ampas dan dimaserasi selama 24 jam. Kedua filtrate digabungkan dan dievaporasi menggunakan rotary evaporator pada suhu $70^{\circ} \mathrm{C}$. Ekstrak yang yang didapat didinginkan di dalam desikator.

\section{Uji Fitokimia}

\section{Uji Flavonoid (Harborne, 1996)}

Ekstrak ditimbang sebanyak $50 \mathrm{mg}$ dan ditambahkan air panas sebanyak $100 \mathrm{~mL}$ kemudian didihkan selama 5 menit dan disaring. $0,05 \mathrm{mg}$ serbuk Magnesium ditambahkan ke dalam filtrat sebanyak $5 \mathrm{~mL}$ dan $1 \mathrm{~mL} \mathrm{HCl}$ pekat, kemudian dikocok dengan kuat. Warna merah magenta yang terbentuk menunjukkan adanya senyawa flavonoid.

\section{Uji Tanin (Harborne, 1996)}

Ekstrak ditimbang sebanyak $50 \mathrm{mg}$ dilarutkan dalam $2 \mathrm{~mL}$ air kemudian ditambahkan 2 tetes larutan $\mathrm{FeCl}_{3} 1 \%$. Adanya tannin ditunjukkkan dengan terbentuknya warna biru kehitaman dan hijau kehitaman.

\section{Uji Saponin (Harborne, 1996)}

Ekstrak ditimbang sebanyak $50 \mathrm{mg}$ kemudian ditambahkan $10 \mathrm{~mL}$ air dan dikocok selama 1 menit.Setelah itu ditambahkan 2 tetes $\mathrm{HCl} 1 \mathrm{~N}$. Adanya saponin ditunjukkan dengan terbentuknya busa yang tetap stabil selama 7 menit.

\section{Penentuan $\mathrm{LC}_{50}$ \\ Uji toksiksitas}

10 ekor udang Artemia salina dimasukkan kedalam larutan uji dengan konsentrasi 1000, 500, 250, 100, $50 \mathrm{mg} / \mathrm{L}$ dan pada control 1 dan control 2.Setiap larutan uji dilakukan 2 kali pengulangan dan dibandingkan dengan kontrol.Pengamatan terhadap udang Artemia salina dilakukan selama 24 jam. Prosentase

kematian udang Artemia salina dihitung dengan persamaan berikut:

$\%$ Mortalitas $=\frac{\text { Jumlah larva yang mati }}{\text { Jumlah larva uji }} \times 100 \%$

Rumus Abbot's digunakan apabila pada kontrol ada udang yang mati:

$\%$ Mortalitas

\% Kematian pada uji-\% Kematian pada kontrol $\mathrm{X} 10$ $0 \%$

$$
\text { 100-\% Kematianpadakontrol }
$$

\section{Penentuan Nilai $\mathbf{L C}_{50}$}

Penentuan nilai $\mathrm{LC}_{50}$ menggunakan metode anilasa probit SPSS 20.0. 


\section{HASIL DAN PEMBAHASAN}

\section{Kadar Air}

Pengujian kadar air terhadap sampel serbuk daun liwas selama 3 kali pengulangan mendapatkan prosentase kadar air kurang dari $10 \%$. Nilai kadar air daun liwas adalah sebesar $2,34 \%$.

Nilai tersebut menunjukkan bahwa kandungan kadar air daun liwas sangat baik karena kurang dari 10\% (Winarno, 1997). Semakin rendah kadar air suatu sampel, akan menghasilkan rendemen yang lebih banyak (Inayati, 2007).

\section{Maserasi}

Metode maserasi dipilih unuk digunakan karena mudah dioperasikan, kerusakan komponen dapat dihindari dan relatif lebih murah, tetapi memiliki kelemahan dari segi waktu yang lebih lama dan penggunaan pelarut yang relatif banyak (Wulandari, 2005). Ekstraksi maserasi dilakukan sebanyak dua kali terhadap sampel daun liwas.Setelah direndam selama $2 \times 24$ jam, diperoleh 19,57 g ekstrak dari $50 \mathrm{~g}$ sampe dengan prosentase rendemen sebesar $39,14 \%$. Penggunaan pelarut metanol dalam proses ekstraksi menghasilkan jumlah ekstrak yang besar. Menurut Khopkar (1980) untuk mendapatkan hasil pemisahan baik, proses ekstraksi harus diulang beberapa kali. Besarnya luas permukaan sampel dan rendahnya kandungan kadar air dari sampel daun liwas menyebabkan jumlah rendemen yang lebih banyak (Inayati, 2007).

\section{Uji Fitokimia}

Uji fitokimia dilakukan sebagai uji pendahuluan untuk mengetahui tentang kandungan senyawa bioaktif yang terkandung di dalam daun liwas. Uji fitokimia ekstrak metanol daun liwas menunjukkan adanya kandungan senyawa bioaktif seperti flavonoid, tannin dan saponin.Menurut Markham (1988) flavonoid dapat larut dalam pelarut polar seperti metanol, sehingga hasil menunjukkan $(+)$ adanya senyawa flavonoid dalam ekstrak metanol daun liwas. Adanya senyawa tannin karena senyawa tannin dapat ditemukan hampir disetiap bagian dari tanaman (Hagerman, 2002). Sedangkan saponin dapat larut dalam air dan dapat menyebabkan tegangan aktif permukaan serta bersifat polar (Wu et al., 2007).

\section{Penentuan Nilai $\mathbf{L C}_{50}$}

Hasil uji brine shrimp lethality test ekstrak metanol daun liwas terhadap udang $A$. salina dapat di lihat pada Tabel 1.

Tabel 1. Hasil Uji Toksisitas

\begin{tabular}{|c|c|}
\hline Konsentrasi (mg/L) & Mortalitas (\%) \\
\hline 0 & 0 \\
\hline 25 & 42,85 \\
\hline 50 & 57,14 \\
\hline 100 & 64,24 \\
\hline 250 & 71,42 \\
\hline 500 & 85,71 \\
\hline 1000 & 100 \\
\hline
\end{tabular}

Berdasarkan data dari (Tabel. 1) dapat dilihat bahwa semakin tinggi konsentrasi ekstrak dalam larutan uji semakin besar jumlah kematian udang A. salina. Semakin besar jumlah udang A. salina yang mati pada larutan uji dengan kandungan ekstrak daun liwas yang kecil menunjukkan pengaruh ekstrak metanol daun liwas dapat mematikan pada konsentrasi yang kecil.

Nilai $\mathrm{LC}_{50}$ diperoleh dari data pada tabel di atas dan dianalis probit menggunakan SPSS 20. Hasil yang dieroleh adalah 15,69 $\mathrm{mg} / \mathrm{L}$. Nilai ini menunjukkan bahwa pada konsentrasi 15,69 mg/L ekstrak metanol daun liwas mampu membunuh larva udang sampai $50 \%$ populasi. Berdasarkan nilai $\mathrm{LC}_{50}$ ekstrak metanol daun limas menunjukan toksiksitas yang sangat baik. Menurut (Meyer et al., 1982), Tingkat toksisitas suatu ekstrak adalah sebagai berikut: $\mathrm{LC}_{50} \leq 30 \mathrm{mg} / \mathrm{L}=$ Sangat toksik; $\mathrm{LC}_{50} \leq 1.000 \mathrm{mg} / \mathrm{L}=$ Toksik; $\mathrm{LC}_{50}>$ $1.000 \mathrm{mg} / \mathrm{L}=$ Tidak toksik.

Kematian 50\% udang A. salina disebabkan oleh kandungan senyawa metabolit sekunder dalam ekstrak metanol daun liwas. Udang A. salina memiliki 
membran kulit yang sangat tipis sehingga difusi zat dari lingkungan yang mempengaruhi metabolisme dalam tubuhnya dapat terjadi (Mudjiman, 1989). Semakin kecil nilai $\mathrm{LC}_{50}$ dari suatu sampel maka semakin tinggi senyawa bioaktifnya. Tingginya aktivitas bioaktif dari ekstrak metanol daun liwas terhadap udang A. salina disebabkan adanya kandungan senyawa saponin dan fenolik yang cukup tinggi (Harborne, 1996). Adanya flavonoid dalam lingkungan sel dapat menyebabkan pecahnya membran sel. pemasukan ion $\mathrm{Na}^{+}$yang tidak terkendali ke dalam sel, yang menyebabkan pecahnya membran sel. Hal ini disebabkan gugus $\mathrm{OH}^{-}$pada flavonoid berikatan dengan protein integral membran sel sehingga terbendungnya transport aktif $\mathrm{Na}^{+}$dan $\mathrm{K}^{+}$. Transpor aktif yang berhenti menyebabkan pemasukan ion $\mathrm{Na}^{+}$yang tidak terkendali ke dalam sel, yang menyebabkan pecahnya membran sel. Pecahnya membran sel inilah yang menyebabkan kematian sel (Scheuer, 1994).

\section{KESIMPULAN DAN SARAN}

\section{Kesimpulan}

1. Ekstrak metanol daun liwas memiliki senyawa bioaktif flavonoid, tannin dan saponin.

2. $\mathrm{LC}_{50}$ ekstrak metanol daun liwas adalah $15,89 \mathrm{mg} / \mathrm{L}$

\section{Saran}

Uji kandungan fitokimia terhadap daun liwas untuk perlu dilakukan lagi terhadap pelarut lain untuk mengetahui kandungan senyawa bioaktif lainnya.

\section{DAFTAR PUSTAKA}

Hagerman, A.E. 2002. Tannin Handbook. Department of Chemistry and Biochemistry. Miami University.

Harbone, J.B. 1996. Metode Fitokimia: Penentuan Cara Modern Menganalisa

Tumbuhan.Terjemahan Kosasih Padmawinata dan Iwang Soediro. ITB, Bandung.

Harmanto, N. 2002. Sehat dengan Ramuan Tradisional.Edisi ke-4. Agromedia Pustaka, Tangerang.
Inayati, H. 2007. Potensi Anti Bakteri Ekstrak Daun Kedondong Bangkok (Spondias dulcis Forst.) [Skripsi]. FMIPAIPB, Bogor.

Khopkar, S.M. 1980. Konsep Dasar Kimia Analitik. Cet. 1 Terjemahan : Saptorahardjo, H., Nurhadi, A. UI Press, Jakarta.

Markham, K.R. 1988. Cara Mengidentifikasi Flavanoid. Divisi kelima Departemen Penelitian Ilmu Pengetahuan dan Industeri, Petone Selandia Baru. Penerbit ITB, Bandung.

Meyer, B.N., N.R. Ferrigni., J.E. Putnam., L.B. Jacobsen., D.E. Nichols., and J.L. Mc Laughlin. 1982. Brine shrimp: A Convenient General Bioassay for Active Plant Constituents. J. Planta Medica. 45(5): 31-45.

Santosa, M.H. 1995. Penyediaan Bahan Penelitian Tumbuhan Obat: Dalam Rapat Kerja Penelitian Tumbuhan Obat Indonesia. Lembaga Penelitian Universitas Airlangga, Surabaya.

Scheuer, J.S. 1994. Produk Alami Lautan. IKIP Semarang Press, Semarang.

Silaban, L.W. 2009. Skrinning Fitokimia dan Uji Aktivitas Anti bakteri dari Kulit Buah Sentul (Sandoricum koetjape (Burm.f.)Merr) terhadap beberapa Bakteri secara in vitro [Skripsi]. Fakultas Farmasi USU, Medan.

Sudarmadji, S., B. Haryono., dan Suhardi.1989. Prosedur Analisis untuk Bahan Makanan dan Pertanian. Liberty, Yogyakarta.

Winarno, M.W. 1997. Efek Daun Katu (Saurophus androgenus Merr.) terhadap Diare Tikus Putih. J. Cermin dunia Farmasi.33:31-35.

Wu, J., Tang., H.M.Wu., and Z.R. Zhou. 2007. Hillasides A and B, Two New Cytoyoxic Triterpene Glycosides from the Sea Cucumber holoyhuria hilla lesson. J. Asian Natural Products Reseach. 9(7):609-615.

Wulandari, N.D.M. 2005. Perbandingan Metode Ekstraksi Buah Mahkota Dewa (Phaleria macrocarpa) dan Uji Toksisitas Sub-kronis pada Tikus Putih [Skripsi]. FMIPA IPB, Bogor. 